\title{
Title of article
}

Implementing an integrated pathway to care for the dying - is your organisation ready?

\section{Authors}

Kendall K Sharpe

Medical Education Registrar

Gold Coast Health, Queensland Australia

Christy Noble

Principal Medical Education Officer and Principal Research Fellow (Allied Health)

Gold Coast Health, Queensland; School of Medicine, Griffith University; School of

Pharmacy, University of Queensland, Queensland Australia

Balaji Hiremagular

Senior Staff Specialist, Nephrology

Gold Coast Health, Queensland

Laurie Grealish

Associate Professor Subacute and Aged Nursing

Gold Coast Health, Queensland; School of Nursing \& Midwifery and Menzies Health

Institute Queensland, Griffith University, Queensland, Australia

\section{Corresponding author}

Laurie Grealish

Gold Coast Health, Queensland; School of Nursing \& Midwifery and Menzies Health Institute Queensland, Griffith University, Queensland, Australia

Work address: 2.05c G01, Gold Coast Campus, Griffith University, Southport QLD 4215

Home address: 72/11-17 Hughes Ave, Main Beach QLD, 4217

Telephone: +61755529558

Email: l.grealish@griffith.edu.au

\section{Acknowledgement}

We wish to acknowledge the support and guidance of Sarah Thorning, the medical librarian at Gold Coast Health. 


\section{Abstract}

Background. Integrated pathways for care of the dying aim to promote the delivery of high quality palliative care regardless of access to specialist services.

Aim. To produce a heuristic to assist with planning and evaluating the integration of the care of the dying pathway into everyday work.

Methods. Electronic databases were searched to identify research papers focused on the implementation of integrated pathways for care of the dying in acute hospital settings. Results. Thirteen articles were reviewed using the four elements of Normalisation Process Theory - coherence, cognitive participation, collective action and reflexive monitoring. These results informed the development of a heuristic for organisational readiness.

Conclusion. The organisational readiness heuristic provides an evidence-based checklist for organisational leaders who are planning to introduce new, or evaluate current, implementation of integrated pathways for care of the dying. The next step is to trial the heuristic for feasibility in practice.

\section{Keywords}

End of life; care; organisational readiness; heuristic; normalization process theory 


\section{Introduction}

Palliative care has emerged as an important field in healthcare internationally. While specialist palliative care services have historically focused on the care of people diagnosed with cancer, the rise of chronic diseases has extended the need for palliative care to noncancer hospital settings (Bostwick et al 2017). For example, in Australia, cancer accounted for around $60 \%$ of separations for palliative care, with another $40 \%$ are attributed to nonneoplastic diseases including heart disease, chronic obstructive airway disease, and pneumonia (Australian Institute for Health and Welfare, 2015). One way for health services to support clinicians working in non-cancer settings to delivery high quality palliative care in the last hours or days of life is provision of an integrated pathway for care of the dying (Ellershaw \& Ward 2003).

The aim of the integrated pathway for care of the dying is to support a person who is in the last hours to days of life to be as comfortable as possible (Ellershaw \& Ward 2003). In a cluster randomized trial, the integrated pathway for care of the dying has been found to improve respect, dignity and kindness, as well as control of physical symptoms such as breathlessness, but it did not improve the overall quality of care (Constantini et al 2014). This scoping study aimed to identify the barriers and facilitators to implementing an integrated pathway for care of the dying to inform the development of a heuristic to assist organisational leaders to determine their readiness to implement an integrated pathway for care of the dying.

\section{Background}

Implementing integrated pathways for care of the dying is challenging. The most established integrated pathway is known as the Liverpool Care Pathway (LCP). The LCP was subject to 
significant broadcast media attention, with many reports of poor treatment in hospitals, particularly at nights and on weekends (Neuberger et al 2013). The poor quality of communication between health professionals and family caregivers accounted for many of the complaints (Neuberger et al 2013). While supporting the principles of the LCP, the implementation was considered problematic (Neuberger et al 2013). There remains limited guidance on how to effectively implement integrated pathways for care of the dying.

The stakes are high when implementing evidence-based guidelines and policies, in that patient care can be compromised if the implementation process is not successful (Proctor et al 2011). In general, when implementing new practices, consideration needs to be given to the type of intervention, the setting and context, the individuals involved and the implementation process (Damschroder et al 2009). Three areas of organisational readiness, motivation to implement an intervention, general capacities of the organisation, and the innovation-specific capacities needed for a particular innovation, have been developed into a simple heuristic (Scaccia et al 2015). This heuristic can be used by organisations to assess readiness to implement an innovation, such as an integrated pathway for care at the end of life. Drawing upon the experiences of others, this review aimed to identify the barriers and facilitators to implementing the integrated pathway for care at the end of life, in order to produce an heuristic of capacities, including innovation-specific capacities, motivation and organisational capacities, required to make the integrated care of the dying pathway part of everyday work.

\section{Methods}

A scoping review was selected because it synthesizes different types of evidence, and identifies gaps in research related to a specific topic in a systematic process (Colquhoun et al 
2014) and is especially useful in emerging areas of research (Anderson et al 2008). The review process followed the process outlined by Mays, Pope and Popay (2005) and focused on the innovation-specific capacities needed to implement an integrated care pathway for care at the end of life. The specific research questions guiding the study were:

1. What are the barriers and facilitators that health professionals encounter to make the integrated pathway for care at the end of life part of their work?

2. What does this mean in terms of organisational readiness to implement the integrated pathway for care of the dying in hospitals?

Search

The review team was multidisciplinary, with backgrounds in medicine, allied health, and nursing. An expert librarian assisted with the search process. A primary search of the literature was undertaken to identify research reporting on 'End of Life' (EOL) pathways in acute, adult health care settings (see Table 1). Records were identified through the PubMed, Embase, Cochrane, AusHealth, PsycInfo, Web of Science and CINAHL databases. The reference lists of all reports identified through the primary search were then hand searched as part of a secondary search strategy. The secondary search strategy was then expanded to include the search terms listed in Table 1 Part B, using the PubMed database only.

[Insert Table 1 here]

\section{Selection and appraisal}

All study designs, regardless of methodological design or quality, were taken into account to identify the complex interplay of factors surrounding implementation. No time restrictions were placed on the search. Articles were excluded if they were in a language other than 
English, set outside the adult acute care setting, used non-empirical methodology or published in non-peer review journals. Two researchers (KS \& CN) reviewed all abstracts identified through the primary and secondary search strategies, with a third researcher (LG) resolving discordance. The process for article selection is outlined in Figure 1.

[Insert Figure 1 here]

Data extraction and analysis:

All articles for review were treated as qualitative data. The focus of the analysis was not on whether the integrated pathway for care of the dying was effective; it was focused on the discussion of implementation. An initial inductive content analysis of the results and discussion sections of each paper was undertaken by all three authors, with KS reviewing all records, and CN and LG verifying half each for comparison with KS.

Normalisation Process Theory (NPT) provided the a priori analytical framework for the data extraction and analysis. NPT is widely recognised as an effective implementation theory (Nilsen 2015) consisting of four elements: coherence, cognitive participation, collective action and reflexive monitoring (May 2013). Coherence refers to the meaningful qualities of a practice; cognitive participation to the enrolment and engagement of individuals and groups; collective action to the interaction with already existing practices; and reflexive monitoring to how a practice is understood and assessed by those people participating in enacting it (May \& Finch 2009). A tool for extracting data was developed, by combining basic background and contextual information with NPT constructs.

Data synthesis 
The identified barriers and facilitators were then synthesized to align with the key capacities associated with organisational readiness: innovation-specific, motivation and organisational capacities (Scaccia et al 2015). Meetings were held on a monthly basis to monitor our progress and discuss issues arising throughout the project.

\section{Results}

Of the 14 papers selected for full review, five were from the United Kingdom, five from Europe (Italy=2, Ireland=1, Netherlands=1, and Belgium=1), two from the United States, and two from New Zealand. The studies were predominantly qualitative in nature, with small and purposeful samples. A description of the studies is found in Table 2. Findings are presented in three sections: barriers to implementation, facilitators to implementation, and a recommended organisational readiness heuristic for implementing an integrated care of the dying pathway.

[Insert Table 2 here]

Barriers to implementing integrated care of the dying pathways

Coherence. When clinicians believe that the care they provide is already consistent with the integrated pathway for care of the dying, the pathway was perceived as unnecessary administrative burden unlikely to improve care, and was therefore less likely to be implemented (Bookbinder 2005 et al; Mellor et al 2004). The amount of seemingly 'redundant' information on the pathway form, and its design as a checklist has led some to the opinion that is not meaningful (Di Leo 2015 et al; Sleeman et al 2014). The fear by senior clinicians that more junior colleagues, or novices, will rigidly apply the pathway irrespective of the clinical scenario also reduces uptake of the integrated pathway for care of the dying. 
This was more pronounced for those who believed that the pathway promotes the binary view of a patient as either 'dying' or 'not dying' (Sleeman et al 2014). The concern that the education will come to focus on the pathway rather than on the general principles of palliative care further discourages its use (McConnell et al 2015; Sleeman et al 2014). Some clinicians expressed concern that death could be considered a medical failure (Di Leo et al 2015) or that medical wards are not the correct environment for end of life care (Di Leo et al 2011). Likewise, some clinicians are anxious that the patient and their family might feel the use of the pathway is negligent and are concerned about the possibilities of litigation and distress that may occur should the patient recover (Clark et al 2012; Di Leo et al 2015; Jack et al 2003).

Cognitive participation. Difficulty in recognising impending death appears to be a major barrier in the use of the integrated care of the dying pathway. This seems to be especially difficult when death occurs out of hours or over the weekend, or where a clinician outside of the primary treating team must initiate the pathway (Clark et al 2012; Di Leo et al 2015; Luhrs et al 2005; Thurston \& Waterworth 2012; Verhofsted et al 2015). It has been suggested that the criteria for starting the integrated care of the dying pathway is vague, raising another obstacle to its use (Di Leo et al 2015). Apprehension about raising the issue of dying with the patient or the family, or the scenario where the family disagreed regarding prognosis, meant that the pathway was often not initiated (Di Leo et al 2015). Finally, difficulty accessing educational programs, or educational content that was inconsistent with the clinician's experience reduced implementation of the integrated care of the dying pathway (Di Leo et al 2011; Di Leo et al 2015). Senior clinicians (doctors) often did not attend educational sessions and some doctors were reluctant to commit to changing their practice (Clark et al 2012; Jack et al 2003; Thurston \& Waterworth 2012). 
Collective action. Resource deficits emerged as a strong factor against integrated care of the dying pathway implementation. Physical resources in the form of private spaces in which to talk with patients and their families, lack of appropriate staff and time in the face of overwhelming documentation, prescription pads and equipment were all highlighted as issues (Bookbinder et al 2005; Clark et al 2012; Di Leo et al 2011; Di Leo et al 2015; McConnell et al 2015; Raijmakers et al 2015; Verhosted et al 2015; Walker et al 2010). 'Psychosocial' work, or spending time with the patient and their families, suffered particularly where time constraints were thought to exist (Di Leo et al 2011; Di Leo et al 2015).

Poor team dynamics and distrust between professions also emerged as a factor inhibiting uptake of the integrated care of the dying pathway. Nursing staff reported frustration when doctors were reluctant to initiate the pathway (Luhrs et al 2005; Thurston \& Waterworth 2012; Walker et al 2010). Disagreement between nurses and doctors regarding the care plan also negatively impacted on the use of the pathway (Di Leo et al 2011; Mellor et al 2004). Other interprofessional factors included the relationship between management and floor staff whereby the engagement of clinicians in pathway implementation was reduced when senior managers reduced support for the integrated care of the dying pathway (McConnell et al 2015).

Reflexive monitoring. Finally, the negative public perception of integrated care of the dying pathways and the sense of negligence felt by the clinician if the patient improves whilst on the pathway were considered barriers to its implementation (Jack et al 2003; McConnell et al 2015). The integrated care of the dying pathway did not provide a vehicle to resolve 
interdisciplinary conflict and when it failed to support complex family negotiations, the pathway was not used (Di Leo et al 2011; McConnell et al 201t).

\section{Facilitators of integrated care pathways for care of the dying}

Coherence. The integrated pathway for care of the dying is more likely to be implemented when it aligns with the clinician's personal understanding of evidence-based palliation and is viewed a guide to prompt care (Clark et al 2012; Di Leo et al 2011; Raijmakers et al 2015). Where the clinician believes that death is a legitimate outcome of care and that the use of an integrated pathway for care of the dying will honour the patient by delivering a good death, it is more likely to be employed (Bookbinder et al 2005; Sleeman et al 2014). The belief that the pathway provides a structured means by which to care for the patient and focus on the relatives' needs, leads to greater use (Jack et al 2003). The integrated pathway for care of the dying is valued as symbolic of the shift from active to palliative treatment, helping clinicians express non-verbally the change in care (McConnell et al 2015; Sleeman et al 2014). Finally, in relation to coherence, the clear outline of the goals of care found in the pathway increases the user's confidence in delivering a better level of care and was also associated with increased use (Clark et al 2012; Thurston \& Waterworth 2012).

Cognitive participation. Overwhelming, the most positive factor in influencing the uptake of the integrated care of the dying pathway was the involvement of a 'change champion', a local unit expert or taskforce that actively encouraged pathway use and was available to support its users (Bookbinder et al 2005; Luhrs et al 2005; McConnell et al 2015; Mellor et al 2004; Raijmakers et al 2015; Verhofsted et al 2015). Following the lead of a more senior colleague, manager or executive committed to the integrated pathway for care of the dying was also beneficial to implementation in the acute hospital setting (McConnell et al 2015; 
Mirando, Davies \& Lipp 2005). The opportunity to work collaboratively with other disciplines, and to engage in group decision-making is yet another collaborative facilitating factor (Clark et al 2012; Raijmakers et al 2015; Verhofsted et al 2015).

Access to education programs developed to support the use of the integrated care of the dying pathway, encourages its use, as did access to an implementation guide (McConnell et al 2015; Walker et al 2010; Verhofsted et al 2015). Where education helped users develop skills in discussing dying with patients and their relatives, and boosted their confidence in withdrawing treatments and managing pain, the integrated care of the dying pathway was more likely to be followed (Di Leo et al 2011, Thurston \& Waterworth 2012, Jack et al 2003, Clark et al 2012).

Collective action. The integrated pathway for care of the dying provided a means to facilitate frank discussions between different disciplines regarding the goals of care helping clinicians recognise the contribution of their colleagues from other disciplines (Mirando et al 2005; Clark et al 2012; Di Leo et al 2011). Access to expert or experienced colleagues was considered an exceptionally desirable aspect of the integrated pathway for care of the dying (Mirando et al 2005; Raijmakers et al 2015). The form was a considered a useful means of sharing information and supported bedside communication between different team members (Sleeman et al 2015; Walker 2010). Likewise, it was considered an excellent tool to support communication or discussions with the patient’s family (Jack et al 2003; Thurston \& Waterworth 2012; Verhofsted et al 2015). Staff meetings to initiate the pathway and to debrief after the death of the patient were also considered factors that promote implementation of the integrated pathway for care of the dying (Bookbinder et al 2005). Even local staff meetings to address potential barriers to physician compliance were deemed useful 
(Luhrs et al 2005; Mirando et al 2005). Attending group educational sessions about end of life care, and learning about end of life care by completing the integrated pathway for care of the dying was also considered a positive factor in the pathway implementation in the acute hospital setting (McConnell et al 2015; Sleeman et al 2015; Verhofsted et al 2015).

Reflexive monitoring. Staff debriefing, where individuals could discuss how a patient's symptoms were managed and share feedback were viewed positively (Bookbinder et al 2005; Di Leo et al 2011; Di Leo et al 2015; Luhrs et al 2005; Thurston \& Waterworth 2012). The opportunity to participate in audits of patient notes on completion of the integrated care of the dying pathway (Di Leo et al 2011) and to evaluate training programs (McConnell et al 2015; Mellor et al 2004; Mirando et al 2005; Raijmakers et al 2015) were also considered facilitating factors in the uptake of integrated pathways for care of the dying.

Organisational readiness for implementing an integrated end of life care pathway In this review, there was strong evidence about barriers and facilitators to implementing end of life care pathways. When these are categorized using the NPT conceptual framework, strategies to promote facilitators and address barriers can be created. When the facilitators and barriers are grouped into organisational capacities (Scaccia et al 2015), a heuristic for implementation planning and evaluation emerged (Table 3). While most organisational characteristics included can facilitate the implementation of an integrated end of life care pathway, the presence of some characteristics are inherent barriers.

[Insert Table 3 here]

\section{Discussion}


In the hospital context, the alignment between clinicians' personal understanding of death as a legitimate outcome of care and that the belief that the integrated pathway for care of the dying can honor the patient by delivering a good death (coherence) is critical for successful implementation. When clinicians believe that their care provision is consistent with the integrated pathway (coherence), then the pathway is seen as an unnecessary administrative burden and unlikely to be implemented well. A key strategy, to align individual understanding of death with organisational imperatives for quality end of life care, may include educational programs on the principles of palliative care, focused on the legitimate shift in focus from cure to comfort in end of life care. In terms of organisational readiness, an accessible education program can support clinicians, especially doctors, to appreciate that in some cases death is not a medical failure and to value comfort at the end of life. A key element in this type of education is to draw upon the deeply held values of clinicians to provide quality care in general, to the care required at the end of life.

In many of the reviewed studies, a change facilitator role was considered important to support clinicians to conceptualize their role (cognitive participation) in the care of the person at end of life. The resourcing of a specific change facilitator role, as well as other indicators of organisational support from senior managers and executives, were considered necessary for clinicians to implement the integrated care of the dying pathways. In terms of organisational capacity to implement integrated care pathways, the usefulness of the pathway to support clear communication between clinicians from different disciplines and clinicians and families is a valued reason to participate. Education, often provided in the context of everyday practice, improved clinician confidence and motivation to use the integrated care pathways. Change facilitators, experienced colleagues and/or specialist palliative care clinicians were all considered sources for practice-based learning. 
To work collaboratively with the integrated care pathway (collective action), several organisational changes are required. Firstly, local multi-disciplinary team meetings are required. At these meetings, opportunities to discuss end of life care matters, including specific cases, can promote interdisciplinary working. Secondly, private spaces for sensitive conversations with families are required. Comfort care requires psychosocial care. While many medical treatments are withdrawn as part of the integrated care of the dying pathway, there is a considerable time required to provide psychosocial care for the person and their family. Further to this, organisational capacity to support multidisciplinary practice is necessary and specific innovation capacities related to mechanisms to support communication among team members and families is critical for clinician motivation, and therefore successful implementation.

As the articles became more recent, the negative public perception of integrated pathways for care at the end of life emerges as a significant consideration by clinicians, especially senior medical officers. Staff awareness of the effects of the integrated pathways for care of the dying (reflexive monitoring) emerged as an important element in implementation. Staff debriefings were used in several studies. Sometimes, the debriefing was supported by audits of patient notes but not always. Organisational capacity to support the innovation is enhanced when there are opportunities for staff to reflect on their end of life care practice collectively. Structured debriefings, with the aim of reflexive monitoring of integrated pathway usage, emerges as another important element so support implementation.

The findings from this study echo those of the realist systematic review of implementation strategies (McConnell et al 2013). Consistent with our findings, key enhancing factors in the 
hospice setting included a dedicated facilitator, education and training, audit and feedback, organisational culture, and adequate resources (McConnell et al 2013). Further to the McConnell led study (2013), clinicians are challenged to accept death as a legitimate outcome (coherence) and significant work is required to support them to align their understanding with the principles of good palliative care. How clinicians perceive their, and other roles in care at the end of life (cognitive participation) requires negotiation and like the hospice setting, a change facilitator is critical in hospitals seeking to implement integrated pathways for care of the dying. While hospice culture values psychosocial care as part of comfort, this is not as culturally relevant in the hospital. Significant organisational changes in the hospital are required to support multidisciplinary ways of working (collective action) that privileges psychosocial care required for quality care of the dying. Finally, like hospice settings, the importance of a clinical governance framework that values audit and feedback, including team reflections on specific cases (reflexive monitoring) is important to ensure high quality care.

\section{Limitations}

During the period of this review, the Liverpool Care Pathway or LCP title was dropped, leading us to use the more generic term, integrated pathway for care of the dying. Prior to the LCP, there was no single term that was used, which may have reduced our ability to find some articles. This study did not include non-English language papers or those set in the paediatric population, so it remains unclear what factors facilitate or impair the implementation of integrated pathways for care at the end of life within these populations.

\section{Conclusion}


As our society continues to age, with an increasing proportion of the older population living with life-limiting disease using hospital services, it important to be ready to provide end of life care in the hospital setting. Cultural change across the hospital organisation is required to support the widespread implementation of quality end of life care. Through this literature review and analysis, specific elements of change have been highlighted including alignment of individual beliefs about death in hospital and care of the dying (coherence), improved clinician understanding of individual roles in care of the dying (cognitive participation), resources to support collaborative working to shift the focus from cure to care (collective action), and legitimate opportunities for staff to discuss their experiences of providing end of life care (reflexive monitoring).

Through this review we have highlighted the factors that both positively and negatively impact the implementation of integrated pathway for care of the dying in the acute hospital setting. We have also added a practical dimension to this area of inquiry in the form of an heuristic, which can be used to review organisational readiness to implement an integrated pathway for care of the dying. Further research into the usefulness of the organisational readiness heuristic is both warranted and desired, particularly where it might influence the reintroduction of potentially useful pathways into clinical practice. 


\section{References}

Australian Institute of Health and Welfare, 2015. Admitted Patient Care 2013-14: Australian hospital statistics. Health Services Series No 60. AIHW: Canberra.

Anderson S, Allen P, Peckham S, Goodwin N (2008) Asking the right questions: scoping studies in the commissioning of research on the organisation and delivery of health services. Health Res Pol Syst 6(7): doi: 10.1186/1478-4505-6-7.

Bookbinder M, Blank AE, Arney E, Wollner D, Lesage P, McHugh M, Indelicato RA, Harding S, Barenboim A, Mirozyev T, Portenoy RK (2005) Improving end-of-life care: development and pilot-test of a clinical pathway. J Pain Symptom Manage 29(6): 529-43

Bostwick D, Wolf S, Samsa G, Bull J, Taylor DH, Johnson KS, Kamal AH (2017). Comparing the palliative care needs of those with cancer to those with common non-cancer serious illness. J Pain Symptom Manage 53(6): 1079-1084

Clark JB, Sheward K, Marshall B, Allan SG (2012) Staff perceptions of end-of-life care following implementation of the liverpool care pathway for the dying patient in the acute care setting: a New Zealand perspective. J Palliat Med 15(4): 468-73

Colquhoun HL, Levac D, O'Brien KK, Straus S, Tricco AC, Perrier L, Kastner M, Moher D (2014) Scoping reviews: time for clarity in definition, methods, and reporting. Journal Clin Epidemiol 67(12):1291-4.

Costantini M, Romoli V, Leo SD, Beccaro M, Bono L, Pilastri P, Miccinesi G, Valenti D, Peruselli C, Bulli F, Franceschini C, Grubich S, Brunelli C, Martini C, Pellegrini F, Higginson IJ, Liverpool Care Pathway Italian Cluster Trial Group (2014). Liverpool Care 
Pathway for patients with cancer in hospital: a cluster randomised trial. Lancet 383(9913): 226-37

Damschroder LJ, Aron DC, Keith RE, Kirsh SR, Alexander JA, Lowery JC (2009) Fostering implementation of health services research findings into practice: a consolidated framework for advancing implementation science. Implement Sci 7:4,50

Di Leo S, Beccaro M, Finelli S, Borreani C, Costantini M (2011) Expectations about and impact of the Liverpool Care Pathway for the dying patient in an Italian hospital. Palliat Med 25(4): 293-303

Di Leo S, Romoli V, Higginson IJ, Bulli F, Fantini S, Sguazzotti E, Constantini M (2015) 'Less ticking the boxes, more providing support': A qualitative study on health professionals' concerns towards the Liverpool Care of the Dying Pathway. Palliat Med 29(6): 529-37

Ellershaw J, Ward C (2003) Care of the dying patient: the last hours or days of life. BMJ 326(7379): 30-34

Jack BA, Gambles M, Murphy D, Ellershaw JE (2003) Nurses' perceptions of the Liverpool Care Pathway for the dying patient in the acute hospital setting. Int J Palliat Nurs 9(9): 37581

Luhrs CA, Meghani S, Homel P, Drayton M, O'Toole E, Paccione M, Daratsos L, Wollner D, Bookbinder M (2005) Pilot of a pathway to improve the care of imminently dying oncology inpatients in a Veterans Affairs Medical Center. J Pain Symptom Manage 29(6): 544-51

May C (2013) Towards a general theory of implementation. Implement Sci 8:18. doi: 10.1186/1748-5908-8-18. 
May C \& Finch T (2009) Implementing, embedding and integrating practices: an outline of Normalisation Process Theory. Sociology 43(3): 535-554

Mays N, Pope C, Popay J (2005) Systematically reviewing qualitative and quantitative evidence to inform management and policy-making in the health field. J Health Serv Res Policy 10 Suppl 1: 6-20

McConnell T, O’Halloran P, Porter S, Donnelly M (2013) Systematic realist review of key factors affecting the successful implementation and sustainability of the Liverpool Care Pathway for the dying patient. Worldviews on Evid Based Nurs 19(4): 218-237. doi: 10.1111/wvn.12003.

McConnell T, O'Halloran P, Donnelly M, Porter S (2015) Factors affecting the successful implementation and sustainability of the Liverpool Care Pathway for dying patients: a realist evaluation. BMJ Support Palliat Care 5(1): 70-7

Mellor F, Foley T, Connolly M, Mercer V, Spanswick M (2004) Role of a clinical facilitator in introducing an integrated care pathway for the care of the dying. Int J Palliat Nurs 10(10):497-501

Mirando S, Davies PD, Lipp A (2005) Introducing an integrated care pathway for the last days of life. Palliat Med 19(1): 33-9

Neuberger J, Aaronvitch D, Bonser T, Charlesworth-Smith D, Cox D, Guthrie C, Hameed K, Lord Harries of Pentregarth, Jackson E, Waller S (2013) More Care, Less Pathway: A Review of the Liverpool Care Pathway. Willams Lea: UK.

Nilsen P (2015). Making sense of implementation theories, models and frameworks. Implement Sci 10: 53-66. doi:10.1186/s13012-015-0242-0. 
Proctor E, Silmere H, Raghavan R, Hovmand P, Aarons G, Bunger A, Griffey R, Hensley M, 2011. Outcomes for implementation research: conceptual distinctions, measurement challenges, and research agenda. Admin Pol Ment Health 38(2): 65-76

Raijmakers N, Dekkers A, Galesloot C, van Zuylen L, van der Heide A (2015) Barriers and facilitators to implementation of the Liverpool Care Pathway in the Netherlands: a qualitative study. BMJ Support Palliat Care 5(3): 259-65

Scaccia JP, Cook BS, Lamont A, Wandersman A, Castellow J, Beidas RS (2015) A practical implementation science heuristic for organisational readiness: R=MC2. Journal of Community Psychol 43(3): 484-501

Sleeman KE, Koffman J, Bristowe K, Rumble C,Burman R, Leonard S (2015) 'It doesn't do the care for you': a qualitative study of health care professionals' perceptions of the benefits and harms of integrated care pathways for end of life care. BMJ Open 14;5:9 doi: 10.1136/bmjopen-2015-008242.

Verhofstede R, Smets T, Cohen J, Costantini M, Van Den Noortgate N, van der Heide A, Dellens L (2015) Development of the care programme for the last days of life for older patients in acute geriatric hospital wards: a phase 0-1 study according to the Medical Research Council Framework. BMC Palliat Care 9;14:24. doi: 10.1186/s12904-015-0025-z

Walker R, Read S (2010) The Liverpool Care Pathway in intensive care: an exploratory study of doctor and nurse perceptions. Int J Palliat Nurs 16(6): 267-73

Worldwide Palliative Care Alliance. Global Atlas of Palliative Care at the End of Life [Internet]. World Health Organisation [cited 2017 May 28]. Available from http://www.thewhpca.org/resources/global-atlas-on-end-of-life-care 


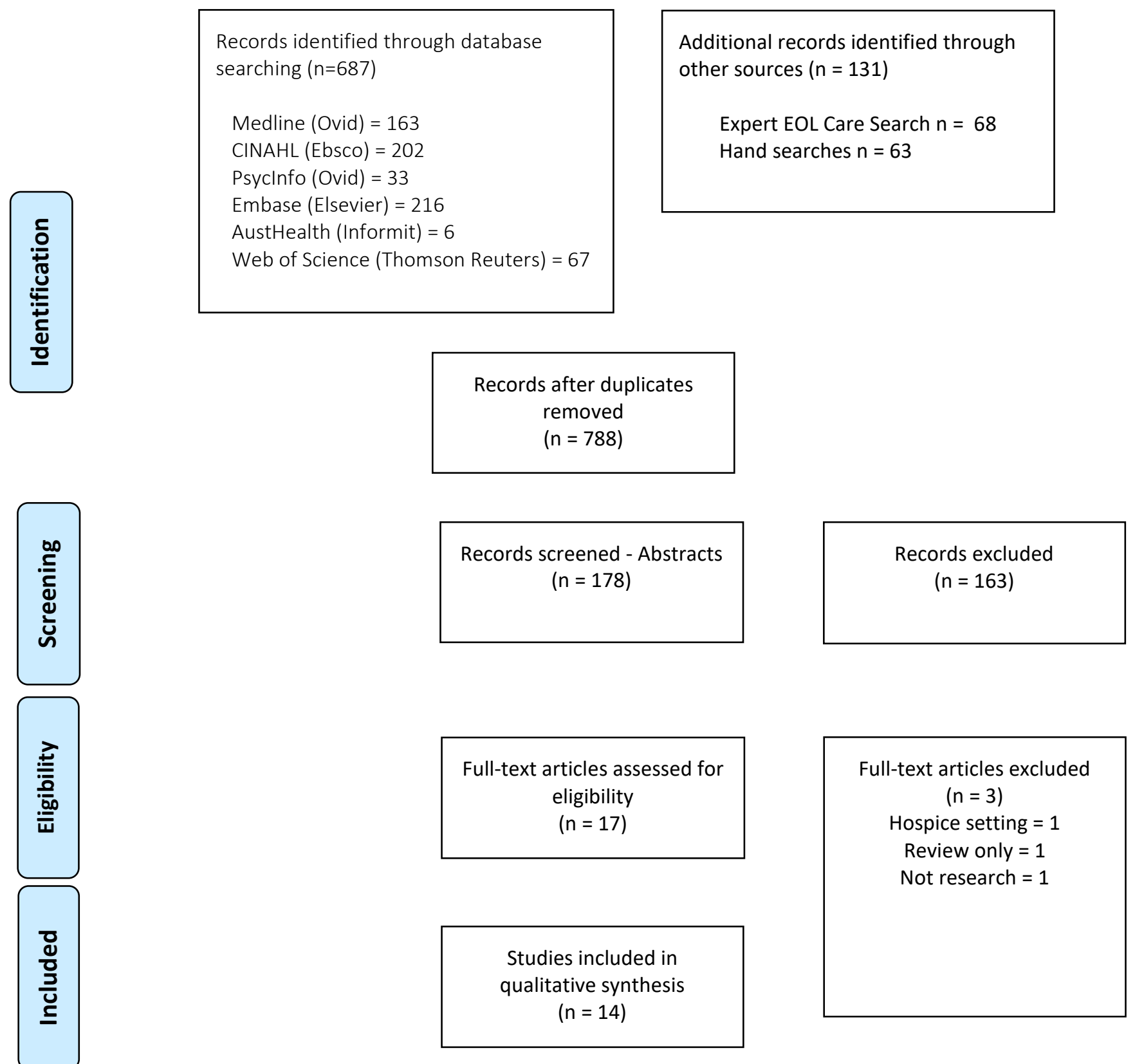

Figure 1 PRISMA Flow Diagram for the primary literature search 


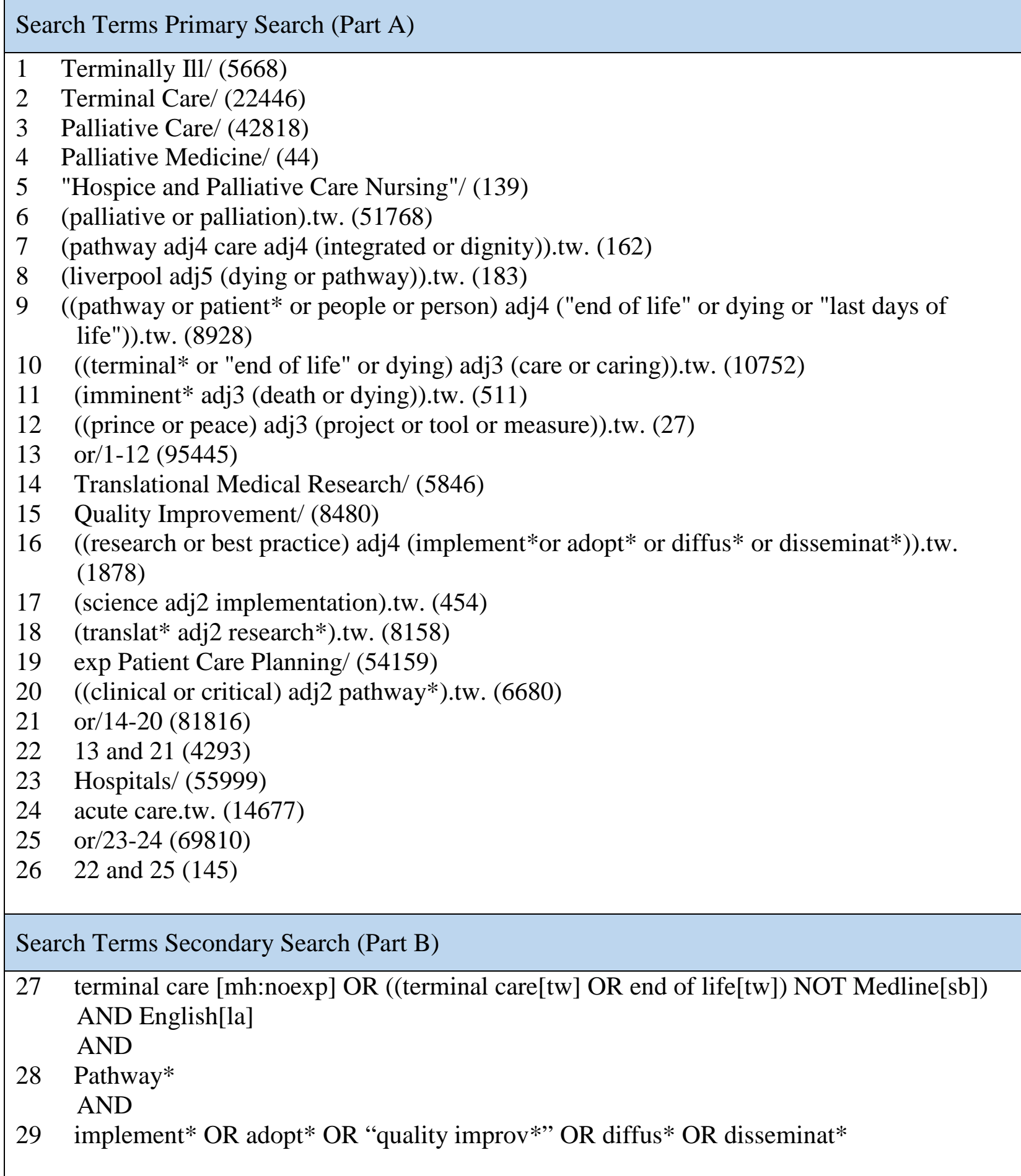


Table 2. Description of included studies 


\begin{tabular}{|c|c|c|c|c|c|}
\hline $\begin{array}{l}\text { First author (year) } \\
\text { Country }\end{array}$ & Aim & Method & $\begin{array}{l}\text { Participants } \\
\text { Setting }\end{array}$ & $\begin{array}{l}\text { Implementation } \\
\text { Facilitators }\end{array}$ & Implementation Barriers \\
\hline $\begin{array}{l}\text { Bookbinder } \\
\text { (2005) } \\
\text { United States of } \\
\text { America }\end{array}$ & $\begin{array}{l}\text { Evaluate the utility of } \\
\text { the Palliative Care for } \\
\text { Advanced Disease } \\
\text { (PCAD pathway }\end{array}$ & $\begin{array}{l}\text { Chart audit plus } \\
\text { anecdotal } \\
\text { reports of } \\
\text { implementation } \\
\text { issues }\end{array}$ & $\begin{array}{l}157 \text { patients who } \\
\text { died } \\
\text { Oncology, } \\
\text { palliative care, } \\
\text { geriatric wards in } \\
\text { one hospital }\end{array}$ & $\begin{array}{l}\text { C: Belief that PCAD } \\
\text { assisted in honouring } \\
\text { patients through promotion } \\
\text { of a peaceful death; } \\
\text { general education on } \\
\text { palliative care } \\
\text { CP: Use of 'champions' } \\
\text { who fostered local } \\
\text { engagement } \\
\text { CA: MDT meetings to } \\
\text { identify patients suitable } \\
\text { for PCAD } \\
\text { RM: Staff debriefing }\end{array}$ & $\begin{array}{l}\text { C: Belief that what they } \\
\text { were doing was already } \\
\text { consistent with the } \\
\text { guidelines. } \\
\text { CP: None } \\
\text { CA: Too much paperwork } \\
\text { to complete } \\
\text { RM: None }\end{array}$ \\
\hline $\begin{array}{l}\text { Clark (2012) } \\
\text { New Zealand }\end{array}$ & $\begin{array}{l}\text { Post-LCP } \\
\text { implementation report } \\
\text { of staff perceptions of } \\
\text { EOL care }\end{array}$ & $\begin{array}{l}\text { Prospective } \\
\text { mixed methods } \\
\text { including } \\
\text { interviews }\end{array}$ & $\begin{array}{l}41 \text { nurses, doctors } \\
\text { and allied health } \\
\text { professionals } \\
\text { Two acute wards } \\
\text { in one hospital }\end{array}$ & $\begin{array}{l}\text { C: Belief that LCP } \\
\text { contributes to improved } \\
\text { care for dying patients } \\
\text { CP: None reported } \\
\text { CA: None reported } \\
\text { RM: None reported }\end{array}$ & $\begin{array}{l}\text { C: Concerns related to } \\
\text { cases where decision for } \\
\text { LCP reversed or family } \\
\text { not aware of dying before } \\
\text { LCP begins } \\
\text { CP: Delayed diagnosis of } \\
\text { death reduces opportunity } \\
\text { to benefit from LCP } \\
\text { CA: Lack of space for } \\
\text { private meetings with } \\
\text { family; high workload } \\
\text { RM: None reported }\end{array}$ \\
\hline
\end{tabular}




\begin{tabular}{|c|c|c|c|c|c|}
\hline $\begin{array}{l}\text { Di Leo (2011) } \\
\text { Italy }\end{array}$ & $\begin{array}{l}\text { Assess the feasibility } \\
\text { of Liverpool Care } \\
\text { Pathway } \\
\text { implementation }\end{array}$ & $\begin{array}{l}\text { Qualitative } \\
\text { thematic } \\
\text { analysis of a } \\
\text { series of four } \\
\text { focus group } \\
\text { meetings }\end{array}$ & $\begin{array}{l}15 \text { doctors and } \\
\text { nurses } \\
\text { One general } \\
\text { medicine ward in } \\
\text { one hospital }\end{array}$ & $\begin{array}{l}\text { C: LCP is a valid tool for } \\
\text { end of life care } \\
\text { CP: Intensive training to } \\
\text { enhance skills in pain } \\
\text { management and family } \\
\text { communication; Palliative } \\
\text { care unit team provides } \\
\text { coaching, telephone } \\
\text { consultation; champions } \\
\text { CA: Doctors valued nurse } \\
\text { communication with } \\
\text { families } \\
\text { RM: Clinical audits for } \\
\text { difficult cases; include } \\
\text { LCP as part of quality } \\
\text { improvement program }\end{array}$ & $\begin{array}{l}\text { C: Medical wards are the } \\
\text { incorrect place to provide } \\
\text { end of life care } \\
\text { CP: Education on end of } \\
\text { life care inconsistent with } \\
\text { clinical experience } \\
\text { CA: Burden of } \\
\text { documentation; lack of } \\
\text { privacy for family } \\
\text { meetings } \\
\text { RM: None reported }\end{array}$ \\
\hline $\begin{array}{l}\text { Di Leo (2015) } \\
\text { Italy }\end{array}$ & $\begin{array}{l}\text { Explore the views of } \\
\text { professionals who, } \\
\text { during the hospital } \\
\text { implementation of the } \\
\text { Italian version of the } \\
\text { Liverpool Care of the } \\
\text { Dying Pathway (LCP- } \\
\text { I), voiced or showed } \\
\text { concerns towards it. }\end{array}$ & $\begin{array}{l}\text { Qualitative } \\
\text { thematic } \\
\text { analysis }\end{array}$ & $\begin{array}{l}6 \text { physicians and } 5 \\
\text { nurses } \\
\text { Six general } \\
\text { medicine wards } \\
\text { from four hospitals }\end{array}$ & $\begin{array}{l}\text { C: None reported } \\
\text { CP: None reported } \\
\text { CA: None reported } \\
\text { RM: None reported }\end{array}$ & $\begin{array}{l}\text { C: End of life care is not } \\
\text { consistent with medical } \\
\text { mission to save lives } \\
\text { CP: Unable to raise the } \\
\text { topic of dying with } \\
\text { patient/family; unable to } \\
\text { recognise when to start } \\
\text { LCP } \\
\text { CA: Difficult to find time } \\
\text { to meet; LCP form too } \\
\text { long } \\
\text { RM: none }\end{array}$ \\
\hline
\end{tabular}




\begin{tabular}{|c|c|c|c|c|c|}
\hline $\begin{array}{l}\text { Jack (2003) } \\
\text { England }\end{array}$ & $\begin{array}{l}\text { Explore how nurses } \\
\text { perceived the impact } \\
\text { of the Liverpool Care } \\
\text { Pathway. }\end{array}$ & $\begin{array}{l}\text { Qualitative } \\
\text { thematic } \\
\text { analysis of } \\
\text { focus groups }\end{array}$ & $\begin{array}{l}15 \text { nurses } \\
\text { Medicine, surgery, } \\
\text { care of the elderly, } \\
\text { intensive care, and } \\
\text { renal unit of one } \\
\text { hospital }\end{array}$ & $\begin{array}{l}\text { C: LCP can improve } \\
\text { symptom control and } \\
\text { reduce unnecessary } \\
\text { routinized care } \\
\text { CP: Confident to } \\
\text { management pain and } \\
\text { discontinue inappropriate } \\
\text { treatments } \\
\text { CA: Engagement with } \\
\text { family improved with LCP } \\
\text { RM: None reported }\end{array}$ & $\begin{array}{l}\text { C: Fear of litigation } \\
\text { (negligence) } \\
\text { CP: Senior doctors not } \\
\text { engaged in using LCP } \\
\text { CA: none } \\
\text { RM: None reported }\end{array}$ \\
\hline $\begin{array}{l}\text { Luhrs (2005) } \\
\text { United States of } \\
\text { America }\end{array}$ & $\begin{array}{l}\text { Report on the } \\
\text { implementation of a } \\
\text { previously developed } \\
\text { clinical pathway for } \\
\text { terminally ill patients, } \\
\text { Palliative Care for } \\
\text { Advanced Disease } \\
\text { (PCAD) }\end{array}$ & $\begin{array}{l}\text { Retrospective } \\
\text { chart review }\end{array}$ & $\begin{array}{l}39 \text { patients } \\
\text { Acute care } \\
\text { oncology unit in } \\
\text { one hospital }\end{array}$ & $\begin{array}{l}\text { C: Posted guidelines for } \\
\text { pharmacological } \\
\text { management of common } \\
\text { symptoms is staff rooms } \\
\text { CP: Appoint specific } \\
\text { quality improvement team; } \\
\text { change champion; } \\
\text { education on how to use } \\
\text { the LCP } \\
\text { CA: Early physician } \\
\text { engagement encourages } \\
\text { others to engage } \\
\text { RM: Feedback } \\
\text { questionnaire and response }\end{array}$ & $\begin{array}{l}\text { C: None reported } \\
\text { CP: Difficulty recognising } \\
\text { eligible patients; complex } \\
\text { interdisciplinary templates } \\
\text { CA: reluctance to initiate } \\
\text { the LCP on weekends or } \\
\text { holidays } \\
\text { RM: None reported }\end{array}$ \\
\hline
\end{tabular}




\begin{tabular}{|c|c|c|c|c|c|}
\hline $\begin{array}{l}\text { McConnell (2015) } \\
\text { Ireland }\end{array}$ & $\begin{array}{l}\text { To identify the } \\
\text { influences that } \\
\text { facilitated or hindered } \\
\text { successful Liverpool } \\
\text { Care Pathway } \\
\text { implementation }\end{array}$ & $\begin{array}{l}\text { Realist } \\
\text { evaluation of an } \\
\text { organizational } \\
\text { case study }\end{array}$ & $\begin{array}{l}22 \text { staff and two } \\
\text { policy makers } \\
\text { Two service } \\
\text { groups: cancer and } \\
\text { specialist services } \\
\text { and acute services } \\
\text { in one NHS trust }\end{array}$ & $\begin{array}{l}\text { C: Education on how the } \\
\text { LCP could benefit patient } \\
\text { care } \\
\text { CP: Facilitator to market } \\
\text { the LCP; LCP perceived as } \\
\text { useful to complete tasks; } \\
\text { senior executive support } \\
\text { CA: Facilitator support of } \\
\text { clinical staff to make } \\
\text { difficult decisions and } \\
\text { change practice } \\
\text { RM: None reported }\end{array}$ & $\begin{array}{l}\text { C: Limited education or } \\
\text { education limited to LCP; } \\
\text { public saw the pathway as } \\
\text { a 'pathway to death' } \\
\text { CP: Removal of the } \\
\text { facilitator reduced } \\
\text { confidence of role in end } \\
\text { of life care; end of life care } \\
\text { not evident priority in } \\
\text { clinical governance } \\
\text { CA: Clinicians' } \\
\text { perceptions of their } \\
\text { respective roles did not } \\
\text { align } \\
\text { RM: Staff unaware of } \\
\text { audit results }\end{array}$ \\
\hline $\begin{array}{l}\text { Mellor (2004) } \\
\text { England }\end{array}$ & $\begin{array}{l}\text { Describe how LCP } \\
\text { was implemented in } \\
\text { one hospital }\end{array}$ & $\begin{array}{l}\text { Descriptive } \\
\text { case study } \\
917 \text { beds in } 47 \\
\text { wards of a large } \\
\text { hospital in UK }\end{array}$ & $\begin{array}{l}30 \text { patient records } \\
\text { and interviews } \\
\text { with staff ( } \mathrm{n}=\text { not } \\
\text { reported) } \\
\text { One hospital in the } \\
\text { NHS trust }\end{array}$ & $\begin{array}{l}\text { C: Ward-based education } \\
\text { on how to use the LCP; } \\
\text { general education on } \\
\text { palliative care } \\
\text { CP: Facilitator encourages } \\
\text { staff engagement in } \\
\text { processes; ward based } \\
\text { palliative care resource } \\
\text { nurse } \\
\text { CA: Confidence when } \\
\text { supported by facilitator } \\
\text { RM: None reported }\end{array}$ & $\begin{array}{l}\text { C: Belief that another } \\
\text { checklist would increase } \\
\text { workload but not improve } \\
\text { care; doctors not available } \\
\text { for group education } \\
\text { CP: None reported } \\
\text { CA: Nurses challenged to } \\
\text { raise end of life care } \\
\text { conversation with medical } \\
\text { officers } \\
\text { RM: None reported }\end{array}$ \\
\hline
\end{tabular}




\begin{tabular}{|c|c|c|c|c|c|}
\hline $\begin{array}{l}\text { Mirando (2005) } \\
\text { United Kingdom }\end{array}$ & $\begin{array}{l}\text { Evaluate and report } \\
\text { the strengths and } \\
\text { weaknesses of } \\
\text { introducing the } \\
\text { integrated care } \\
\text { pathway }\end{array}$ & $\begin{array}{l}\text { Descriptive } \\
\text { case study } \\
\text { using medical } \\
\text { record audit, } \\
\text { monitoring } \\
\text { variances, } \\
\text { evaluation of } \\
\text { training and } \\
\text { field notes. }\end{array}$ & $\begin{array}{l}50 \text { patients } \\
12 \text { clinical areas in } \\
\text { a district hospital } \\
\text { and six community } \\
\text { hospitals }\end{array}$ & $\begin{array}{l}\text { C: Staff see the need to } \\
\text { change; project nurse is } \\
\text { easily available } \\
\text { CP: Strong support from } \\
\text { ward manager } \\
\text { CA: None reported } \\
\text { RM: None reported }\end{array}$ & $\begin{array}{l}\text { C: Project nurse not } \\
\text { available for consultation } \\
\text { CP: None reported } \\
\text { CA: None reported } \\
\text { RM: None reported }\end{array}$ \\
\hline $\begin{array}{l}\text { Raijmakers (2015) } \\
\text { Netherlands }\end{array}$ & $\begin{array}{l}\text { Evaluates barriers and } \\
\text { facilitators to } \\
\text { implementation of the } \\
\text { Liverpool Care } \\
\text { Pathway }\end{array}$ & $\begin{array}{l}\text { Qualitative } \\
\text { study of } \\
\text { stakeholder } \\
\text { views }\end{array}$ & $\begin{array}{l}28 \text { stakeholders } \\
\text { involved in } \\
\text { implementation of } \\
\text { the LCP } \\
10 \text { health } \\
\text { organisations } \\
\text { across the } \\
\text { Netherlands }\end{array}$ & $\begin{array}{l}\text { C: Believe that the LCP is } \\
\text { evidence-based; clear } \\
\text { goals of care for practice } \\
\text { CP: Value of management } \\
\text { commitment } \\
\text { CA: Sufficient time and } \\
\text { resources to provide care; } \\
\text { support from experts } \\
\mathbf{R M} \text { : continuous audit and } \\
\text { feedback }\end{array}$ & $\begin{array}{l}\text { C: None reported } \\
\text { CP: Competing } \\
\text { organisational priorities } \\
\text { reduce commitment to } \\
\text { LCP } \\
\text { CA: Poor integration with } \\
\text { medical system records } \\
\text { RM: Too few deaths to } \\
\text { develop expertise }\end{array}$ \\
\hline
\end{tabular}




\begin{tabular}{|c|c|c|c|c|c|}
\hline $\begin{array}{l}\text { Sleeman (2015) } \\
\text { England }\end{array}$ & $\begin{array}{l}\text { To understand } \\
\text { healthcare } \\
\text { professionals' } \\
\text { perceptions of the } \\
\text { benefits and potential } \\
\text { harms of integrated } \\
\text { pathways for end-of- } \\
\text { life care }\end{array}$ & $\begin{array}{l}\text { Qualitative } \\
\text { interview study } \\
\text { and thematic } \\
\text { analysis }\end{array}$ & $\begin{array}{l}13 \text { nurses, } 9 \\
\text { doctors, } 3 \text { allied } \\
\text { health } \\
\text { professionals } \\
\text { One south London } \\
\text { hospital }\end{array}$ & $\begin{array}{l}\text { C: Integrated pathway } \\
\text { provides symbol of shift in } \\
\text { care } \\
\text { CP: Novice clinicians can } \\
\text { see their role in integrated } \\
\text { end of life care } \\
\text { CA: The pathway provides } \\
\text { a communication tool } \\
\text { between clinicians; using } \\
\text { the tool enhances learning } \\
\text { about care of the dying } \\
\text { RM: None reported }\end{array}$ & $\begin{array}{l}\text { C: Concerns the pathway } \\
\text { would be applied too } \\
\text { rigidly by junior staff - } \\
\text { limited to a tick box } \\
\text { exercise; narrowly defines } \\
\text { patients as dying or not } \\
\text { dying } \\
\text { CP: None reported } \\
\text { CA: None reported } \\
\text { RM: None reported }\end{array}$ \\
\hline $\begin{array}{l}\text { Thurston (2012) } \\
\text { New Zealand }\end{array}$ & $\begin{array}{l}\text { Explore nurses' } \\
\text { experiences of the } \\
\text { introduction of the } \\
\text { Liverpool Care } \\
\text { Pathway }\end{array}$ & $\begin{array}{l}\text { Qualitative } \\
\text { focus groups } \\
\text { using content } \\
\text { and thematic } \\
\text { analysis }\end{array}$ & $\begin{array}{l}\text { Two focus groups; } \\
\text { one from medical } \\
\text { ward ( } \mathrm{n}=5 \text { nurses) } \\
\text { and surgical ward } \\
(\mathrm{n}=5) \text { in one } \\
\text { tertiary teaching } \\
\text { hospital }\end{array}$ & $\begin{array}{l}\text { C: LCP is a good guide } \\
\text { CP: LCP legitimates } \\
\text { nurses role in care for the } \\
\text { person who is dying in a } \\
\text { culture focused on cure } \\
\text { CA: LCP improves } \\
\text { communication between } \\
\text { team and family; nurses } \\
\text { felt confident to challenge } \\
\text { doctors on care aspects } \\
\text { RM: Evaluation } \\
\text { documentation provides } \\
\text { debriefing for nurses }\end{array}$ & $\begin{array}{l}\text { C: Concerns regarding } \\
\text { transition from 'cure' to } \\
\text { 'care', opioid use, and } \\
\text { being too close to patients } \\
\text { CP: } \\
\text { CA: Prefer meaningful } \\
\text { qualitative words to } \\
\text { tickbox; some doctors do } \\
\text { not use the LCP } \\
\text { RM: None reported }\end{array}$ \\
\hline
\end{tabular}




\begin{tabular}{|c|c|c|c|c|c|}
\hline $\begin{array}{l}\text { Walker (2010) } \\
\text { England }\end{array}$ & $\begin{array}{l}\text { Explore doctors' and } \\
\text { nurses' experiences of } \\
\text { using the Liverpool } \\
\text { Care Pathway }\end{array}$ & $\begin{array}{l}\text { Qualitative } \\
\text { using } \\
\text { descriptive } \\
\text { phenomenology }\end{array}$ & $\begin{array}{l}1 \text { doctor and } 5 \\
\text { nurses } \\
\text { Intensive care unit } \\
\text { in one hospital in } \\
\text { northwest } \\
\text { midlands district }\end{array}$ & $\begin{array}{l}\text { C: None reported } \\
\text { CP: None reported } \\
\text { CA: Consistent } \\
\text { documentation improves } \\
\text { communication } \\
\text { RM: None reported }\end{array}$ & $\begin{array}{l}\text { C: Cynical about how the } \\
\text { LCP improves care; } \\
\text { doctors not familiar with } \\
\text { LCP; families } \\
\text { misunderstand the } \\
\text { diagnosis } \\
\text { CP: } \\
\text { CA: Nurses need to } \\
\text { suggest commencement of } \\
\text { LCP while doctors are } \\
\text { responsible; } \\
\text { Documentation is doubled } \\
\text { RM: None reported }\end{array}$ \\
\hline $\begin{array}{l}\text { Verhofsted (2016) } \\
\text { Belgium }\end{array}$ & $\begin{array}{l}\text { Determine the } \\
\text { feasibility of } \\
\text { implementing the } \\
\text { Care Programme for } \\
\text { the Last Days of Life }\end{array}$ & $\begin{array}{l}\text { Two phase } \\
\text { mixed methods } \\
\text { study including } \\
\text { observation, } \\
\text { interview and } \\
\text { use of a } \\
\text { quantitative } \\
\text { process } \\
\text { evaluation tool }\end{array}$ & $\begin{array}{l}4 \text { geriatricians and } \\
39 \text { nurses } \\
\text { Acute geriatric } \\
\text { ward in one } \\
\text { hospital }\end{array}$ & $\begin{array}{l}\text { C: None reported } \\
\text { CP: Nurse and physician } \\
\text { facilitators engaged staff } \\
\text { CA: Documentation } \\
\text { assisted communication } \\
\text { between team members } \\
\text { RM: None reported }\end{array}$ & $\begin{array}{l}\text { C: Physicians disagree } \\
\text { with content of the } \\
\text { Programme } \\
\text { CP: Physicians remained } \\
\text { unengaged in training, } \\
\text { audit } \\
\text { CA: Steering group lacked } \\
\text { authority/ influence from } \\
\text { management; } \\
\text { documentation was not } \\
\text { completed } \\
\text { RM: None reported }\end{array}$ \\
\hline
\end{tabular}

$\mathrm{C}$ = coherence; $\mathrm{CP}$ = cognitive participation; $\mathrm{CA}$ = collective action; $\mathrm{LCP}=$ Liverpool Care Pathway; MDT = multidisciplinary team; $\mathrm{PCAD}=$ Palliative Care for Advanced Disease; RA = reflexive action 
Table 3. Draft organisational readiness heuristic for implementing the integrated care of the dying pathway

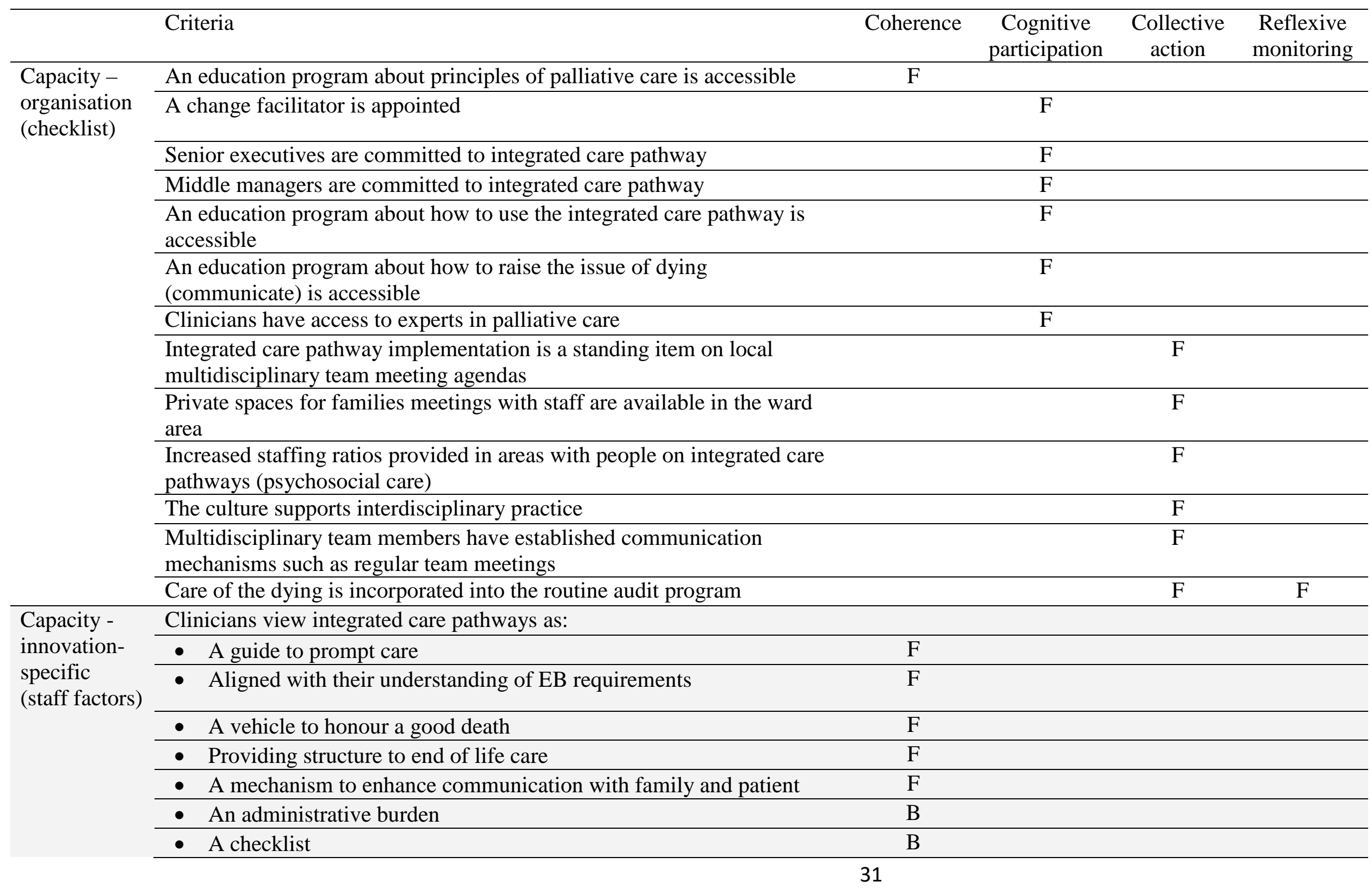




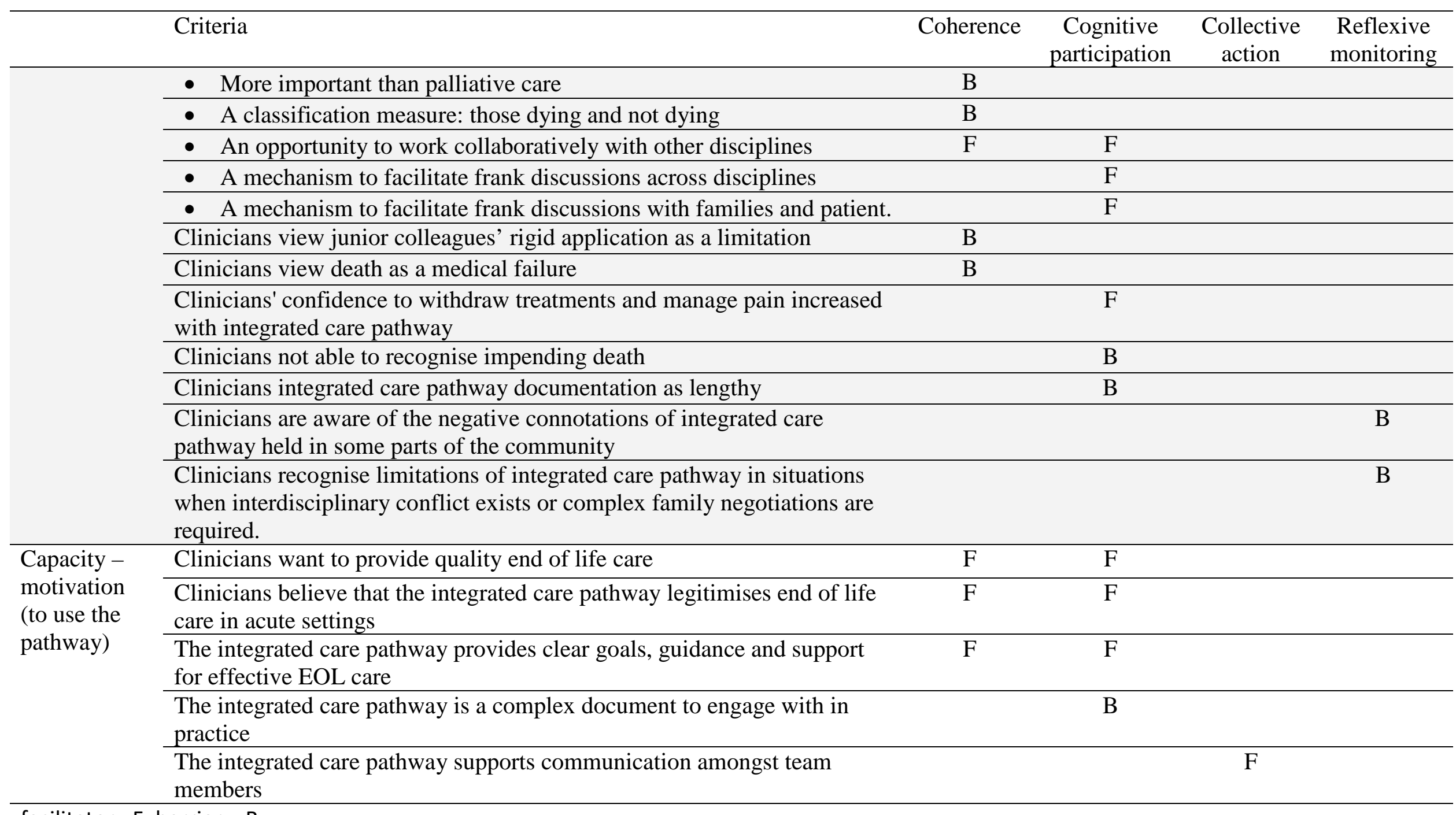

facilitator $=\mathrm{F}$; barrier $=\mathrm{B}$ 